\title{
The English Crown and the election of Pope John XXII*
}

The historiography overall agrees that the move of the papacy to Avignon opened a new period not only in the history of the Medieval Church, but also in the history of Anglo-papal relations. Historians have debated the nature of Anglo-papal relations after the election of Pope Clement V and his legacy, especially because of his Gascon background, his allegiances as a former subject of the English Crown and his international role as mediator between England and France. ${ }^{\mathrm{i}}$ Likewise, the issue of continuity in Anglo-papal relations has been raised when considering the aftermath of Clement V's death on 6 April 1314 at Roquemaure and the lengthy procedure that finally led to the election of Pope John XXII on 7 August 1316. As Wright put it, "the numerous strong ties between Clement and Edward II have often been discussed, and with certain modifications this close relationship between pope and king continued throughout the reign of John XXII. What had been established during the pontificate of Clement V could continue under that of his successor at least partly because they were both dealing with the same English king for the major parts of their pontificates.". ${ }^{i i}$ Wright challenged previous arguments put forward by Tout and Pantin, who had emphasised the weakness and conciliatory attitude of Edward II before the papacy, and supported the conclusions of McKisack, who had focused on the assertive nature of Edward II's rule vis-à-vis the Church, especially as far as ecclesiastical taxation was concerned. ${ }^{i i i}$ In a similar fashion, more recently Patrick Zutshi has highlighted that, despite some moments of friction, Edward II overall received important financial favours from the papacy, while Peter Heath has remarked that the Church lost more ground in England under Edward II than under his father, especially with regard to taxation, jurisdiction, provisions, patronage and vacancies. ${ }^{\text {iv }}$

What makes the question concerning continuity in Anglo-papal relations between the 1310s and 1320s even more remarkable are arguably the efforts of the English Crown to secure a suitable candidate who could succeed to the Apostolic See after Clement V's death. As Seymour Phillips has recently argued, the papal vacancy in fact coincided with very troublesome years for Edward II, 
who had to negotiate the aftermath of his devastating defeat at Bannockburn on 23-24 June 1314, along with adverse economical conditions, prompted by the Great Famines of 1315, 1316 and 1317, and the political opposition in the Westminster Parliament of January-March 1315. Furthermore, in these two years uprisings in Ireland (summer 1315) and Wales (1315-1317) and the rebellion of Thomas, earl of Lancaster, during Autumn 1315 threatened Edward II's rule. ${ }^{v}$ Accordingly, between 1313 and 1316 the English control over the Duchy of Aquitaine represented a main concern for Edward II. The Anglo-French war between 1294 and 1298, which resulted in the French occupation of the Duchy of Aquitaine until May 1303, had in fact prompted Edward I to discharge his debts and obligations towards his loyal Gascon vassals and to grant them compensations and reparations for the war losses in the first decade of the fourteenth century, overall reinforcing the Gascon loyalty to the Plantagenets and underlining the fragile authority of the French Crown over this region. ${ }^{\mathrm{vi}}$ While, in Malcolm Vale's words, between 1314 and 1316 the French Crown considered the Anglo-French negotiations on Aquitaine as "part of a lawsuit between unequals", the French campaigns in Flanders put Edward II in a strong position. ${ }^{\text {vii }}$ This state of affairs was addressed through fresh Anglo-French negotiations in 1313, the mission of Queen Isabella to the French Crown in 1314 and the earl of Pembroke and the bishop of Exeter's embassy to France in May 1315. ${ }^{\text {viii }}$ Arguably, securing the election of a favourable candidate to the Apostolic See after the death of the Gascon pope Clement V, who had demonstrated his allegiance to the English Crown on several occasions, was therefore crucial to Edward II's policy in the region.

The latter point is even more relevant in light of the fact that between 1314 and 1316 the Gascon cardinals, ultimately born as subjects of the English Crown, represented the leading faction in the conclave. Equally, at the death of Clement V in 1314 the English Crown was unable to influence directly the election of his successor through its own cardinals, since the only English cardinal promoted under Clement V, the Dominican Thomas Jorz, had died in 1310 and had not been replaced with another Englishman. ${ }^{\text {ix }}$ 
Regardless of the English Crown's critical influence within the European political milieu between 1314 and 1316, historians have not systematically investigated the involvement of Edward II in the negotiations that led to John XXII's election, apart from few brief and scattered mentions. ${ }^{\mathrm{X}}$ This is mainly due to the fact that the literature has overlooked the rich dossier of diplomatic documents, which were dispatched from England to the papal curia between May 1314 and the end of August 1316. This dossier includes a total of sixteen documents, found among the Chancery records in The National Archives in London. These are a number of petitions, enrolled in the Roman Rolls, which Edward II mainly addressed to the cardinals during the vacancy; ${ }^{\mathrm{xi}}$ one letter sent from Carpentras to the English king after the Gascon attack against the Italian cardinals during the summer 1314; ${ }^{x i i}$ and finally two letters dispatched from France to England by the English representatives at the papal curia. ${ }^{\text {xiii }}$ The importance of this dossier is even more remarkable if compared with the well-known documentation dispatched by the diplomatic envoys of the Aragonese Crown at the papal curia, which has been studied in depth and is renowned as a seminal source for the study of diplomacy during the papal vacancy of 1314-1316, although it only includes fourteen documents published by Finke in $1908 .^{\text {xiv }}$ This essay will therefore try to remedy this neglect, looking at the surviving Anglo-papal diplomatic correspondence for the years 1314-1316 and assessing the effectiveness of Edward II's political influence in the election of John XXII.

As is well-known, the sixty-two year old Provençal cardinal Jacques d'Euse was elected as Pope John XXII after two long years of vacancy and the concrete possibility of a schism. The election of John XXII took place in three distinct phases: initially the cardinals met at Carpentras, where the conclave was summoned between 1 May and 24 July 1314, when Gascon mercenaries attacked the conclave, forcing the Italian cardinals to flee the town; a second phase of papal vacancy between August 1314 and June 1316, when several diplomatic attempts were put forward by the English, Aragonese and French Crowns to agree on the timing and location of the new 
conclave; and finally, a third phase, when the conclave was once more summoned in Lyons on 28 June 1316 and eventually agreed on Pope John XXII's election on 7 August. Yet, long papal vacancies were not unprecedented in the history of the twelfth- and thirteenth-century papacy.

In 1059 Pope Nicholas II had already tried to reform the procedure for papal election, reserving to the cardinals the right of electing the pope. ${ }^{\mathrm{xv}}$ However, between 1119 and 1178 two major papal schisms broke out (between 1130-1139 and 1159-1177). In 1179, at the opening of the Third Lateran Council, it was therefore left to Pope Alexander III, whose pontificate saw the opposition of three anti-popes between 1159 and 1177, to issue a new decree, Licet de vitanda, concerning papal elections. Alexander III's decree acknowledged the unlikelihood of a majority among the cardinals during papal elections and therefore supplemented previous rulings, especially Nicholas II's decree of 1059 , establishing that the new pope should be elected by a two-thirds majority of cardinals' votes. ${ }^{\text {xvi }}$ The procedure of elections was further addressed in canon 24, Quia propter, of the Fourth Lateran Council (1215), although without any direct reference to papal elections. Quia propter in fact decreed that elections could take place in three ways: electio per scrutinium, where three trusted members of the electoral college counted the secret ballot and published the outcome of the election in writing; electio per compromissum, when the election was delegated to a commission of arbiters (generally three); and finally electio per inspirationem, when there was an agreement of the electoral college on one candidate. ${ }^{x v i}$ As Paravicini Bagliani has pointed out, these different procedures were all adopted in papal elections in the first half of the thirteenth century. For instance, after the death of Honorius III in 1227 the cardinals initially agreed per compromissum on Conrad of Urach, cardinal-bishop of Porto, who refused, and then elected per inspirationem Gregory IX - Ugolino of Ostia. ${ }^{\text {xiii }}$

All in all, these rulings concerning papal elections were largely successful and between 1179 and 1271 the Apostolic See was only vacant for about four years. ${ }^{\text {xix }}$ On 1 November 1274 at the Second Council of Lyons, Pope Gregory X, who had been elected after a thirty-three months 
vacancy, ruled on papal elections and more specifically on the conclave in the constitution $U b i$ periculum. This decree gave very detailed indications of the place, timing and procedures of the conclave as well as the income of the cardinals during papal vacancies. Arguably, Gregory X's decree on papal elections represented a very stern procedure for the celebration of the conclave, aiming at shortening the time of papal vacancies and eliminating the secular influences on papal elections. In practice Gregory X's decree encountered a lot of resistance and in the first two decades after its appearance it was only applied in the two papal elections of 1276 , which elected Innocent V and Hadrian V. John XXI, elected on 2 September 1276, suspended Ubi periculum on 30 September 1276 and this decision was followed by three papal vacancies, which lasted over six months. ${ }^{\mathrm{xx}}$ Finally, on 5 July 1294 Celestine V reinstated Ubi periculum, which was followed during the election of Boniface VIII, which was decided per scrutinium after only one day of conclave on 24 December 1294. Boniface VIII further endorsed Ubi periculum and had it included in his collection of decretals promulgated in 1298, the Liber Sextus. ${ }^{\text {xi }}$ Once more, Ubi periculum's legacy was short-lived and in the early fourteenth century the decree was overruled in practice. In 1305 the conclave for the election of Clement $\mathrm{V}$ in fact lasted eleven months. ${ }^{x i i}$ Therefore, at the end of this pontificate at the Council of Vienne (1311-1312), Clement V tried to avoid the occurrence of the same problems through the publication of a new constitution on papal elections, $\mathrm{Ne}$ Romani, which further focused on the protocol of administration of the Apostolic See during papal vacancies and the location of the conclave. .xiii $^{\text {in }}$

As Mollat put it, the practices followed in the election of John XXII ought to be understood within the development of the canonical procedure for papal elections in the second half of the thirteenth century. ${ }^{x x i v}$ On 1 May 1314, in accordance with Ubi periculum, ten days after Clement V's death at Roquemaure on 20 April 1314, the cardinals were summoned to the conclave at the episcopal palace of Carpentras, which was situated about $30 \mathrm{~km}$ from the location where the pope 
had died. The harshness of the conclave at Carpentras is described in the so-called Vita Prima of John XXII, which is contained in the Memoriale historiarum of John, canon of St. Victor in Paris (1327-1351), and was probably written before $1326 .{ }^{\mathrm{xxv}}$ John of St. Victor indeed remarked on the withdrawal of food from the cardinals apart from bread, wine and water as well as the decay of the cardinals' households owing to the suspension of any payment from the Apostolic Chamber - both these pronouncements had been decreed in Ubi periculum to shorten the duration of the conclaves. $^{\text {xxvi }}$

From the very beginning the cardinals were divided into three parties: the Gascon cardinals, who were ten and represented the majority under the external control of two nephews of Clement V, Bertrand de Got, the viscount of Lomagne et Auvillars, and Raimond Guilhem de Budos; the Italian party, which comprised seven cardinals and was itself divided into factions; and the FrenchProvençal party, which included six cardinals from Languedoc, Quercy and Normandy. ${ }^{\text {xxvii }}$ The Italian and Provençal parties initially favoured the election of the Provençal Guillaume de Mandagout, cardinal-bishop of Palestrina, but they encountered the opposition of Bérenger Frédol, who was cardinal-bishop of Tusculum and major penitentiary and had aspirations to the Apostolic See. Likewise, the Gascon cardinals preferred a Gascon pope to succeed Clement V. These divisions made it impossible to agree on a two-thirds majority, as prescribed in Licet de vitanda. A very interesting insight into the on-going negotiations during the conclave is provided in a letter sent to Philip IV, King of France, by the Italian Napoleone Orsini, cardinal of S. Adriano, in defiance of Ubi periculum, which decreed very strict rules on the cardinals' enclosure during the conclave. In his letter Napoleone Orsini blamed Clement V and his rule for the conclave's inability to reach a two-thirds majority at Carpentras. In Napoleone Orsini's words, Clement V was ultimately responsible because of his patronage and nepotism towards his Gascon peers, especially the appointment of Gascons to the cardinal ranks, which had bad repercussions on the current conclave in 1314, and the move of the papal curia to France, which had devastating consequences 
on Rome, Italy and the Church. ${ }^{\text {xxviii }}$ The historiography has however read such remarks as Napoleone's admission of responsibility, since he had been one of the main advocates of Clement V's election at Perugia in 1305. ${ }^{x i x}$ Most interestingly, the same view of Napoleone's influence on Clement V's election was also shared in the contemporary letter that Dante Alighieri addressed to the Italian cardinals during the first phases of the conclave in Carpentras (May-June 1314), also known to Giovanni Villani, who mentions it in his chronicle in the chapter dedicated to Dante. ${ }^{\mathrm{xx}}$ Napoleone further maintained the current intention of the Italian cardinals to elect a pope, good in words and deeds, who could return the Apostolic See to Rome and reform the Church from simony and corruption. ${ }^{x x i}$ Napoleone Orsini finally emphasised that the Italian cardinals had endorsed the election of the Provençal Guillaume de Mandagout, who had an outstanding reputation among the clergy and the faithful as well as among his peers. To their surprise, the Gascons had however rejected Guillaume's candidacy. ${ }^{\text {xxii }}$ Therefore, in utter defiance of Ubi periculum, Napoleone Orsini openly asked Philip IV to intervene with the Gascon cardinals in order to secure a prompt papal election. ${ }^{\text {xxxiii }}$

Arguably, Napoleone Orsini's appeal to Philip IV does not represent the only occurrence when reserved information leaked out of the conclave in Carpentras. Hitherto overlooked evidence, preserved in The National Archives in London, shows that in 1314 Edward II was already worried that the papal vacancy could affect the delicate political balance in Gascony and Aquitaine. As early as 27 May 1314 he therefore activated his diplomatic channels, dispatching to Carpentras his envoys Alexander, bishop of Dublin, Raymond Subirani and Andrea Sapiti. Their letter of credence Edward II directly addressed Bérenger Frédol, who was major penitentiary and regent during the papal vacancy, while copies of the same letter (littere a pari) were also sent to the other cardinals and Clement V's nephews, Bertrand de Got, the viscount of Lomagne et Auvillars, and Raimond Guilhem de Budos. As Edward II clarified in a second letter, dispatched on 26 May 1314 to one of his envoys at the papal curia, Raymond Subirani, he was especially worried that a prolonged papal 
vacancy would affect the payment of arrears owed to the English Crown for the Duchy of Aquitaine, which Pope Clement V had facilitated through a loan in 1312. ${ }^{\text {xxiv }}$ One month later, on 29 June 1314, worried about the inability of the conclave to reach a decision, Edward II again addressed the cardinals, and directly Beregar Frédol. In his letter to the cardinals Edward II expressed his concern for the prolonged vacancy of the Apostolic See, which had deprived the Church of his leader, and asked for a prompt election of the pope, since the vacancy endangered the organization of the crusade to the Holy Land, launched at the Council of Vienne in 1311-1312 and planned for 1319. ${ }^{\mathrm{xxx}}$ In his subsequent letter to Bérenger Frédol, Edward II addressed its recipient more directly, asking that the cardinals pursue any lawful means to agree on a canonical election of the pope as quickly as possible. ${ }^{\text {xxxvi }}$ Finally, on 18 July 1314, Edward II wrote to the Gascon cardinals Arnaud d'Aux, Raimond Guilhem de Farges and Arnaud Pellegrue, along with Clement V's nephew Bertrand de Got, asking for their endorsement of the petitions of his Gascon subjects, Oliver of Bordeaux and his brothers, who asked for 400 silver pounds in compensation and to retain as bailli the bastides of Monflanquin and Castillonnès in the Agenais. ${ }^{\text {xxxvii }}$ Obviously, despite the prolonged papal vacancy, ordinary affairs needed to move on, especially in the Duchy of Aquitaine, and this was undoubtedly Edward II's principal concern. ${ }^{\text {xxxviii }}$

However, a few days later, on 23 and 24 July 1314 riots broke out in Carpentras between the Italian curialists and members of the Gascon cardinals' households. Ultimately, with the excuse of restoring order in the town, Clement V's nephews, the viscount of Lomagne et Auvillars and Raimond Guilhem de Budos, and their mercenaries stormed Carpentras, slaughtering the Italians, assaulting the residence of the Italian cardinals and the headquarters of the Italian bankingcompanies. Finally, the Gascons attacked the conclave. The attack on the conclave in Carpentras in July 1314 is once more well-documented in the English diplomatic correspondence thanks to an original letter sent by the Italian cardinals to Edward II on 10 September $1314 .{ }^{\text {xxxix }}$ In their letter to the English king, the five Italian cardinals openly denounced the Gascon attack and, in a very vivid 
language, they manifested their intention of establishing the truth beyond any rumour. ${ }^{\mathrm{xl}}$ In accordance with Napoleone Orsini's letter to Philip IV, the Italians maintained their intention of supporting a candidate who could reform the Church, neglecting their individual preferences and agendas - this was the Provençal cardinal Guillaume de Mandagout, who however is not explicitly mentioned in the letter. ${ }^{\text {xli }}$ Nevertheless, the Gascons under the command of Clement V's nephews, believing that they had hereditary rights over the Apostolic See, stormed Carpentras, killing some Italian curialists, sacking the Italian cardinals' households and ultimately attacking the episcopal palace, where the conclave was held. ${ }^{x l i i}$ Yelling "we want a pope, kill the Italian cardinals", they finally entered the episcopal palace, and the Italians only managed to escape through a small hole in the back wall, fleeing from Carpentras to different places and ultimately repairing at Valence, from where they wrote to Edward II. ${ }^{\text {xliii }}$ Indeed, the choice of Edward II as the addressee of the Italian complaints against the Gascon attack seems very appropriate, since the English king after all ruled over part of Gascony, while most interestingly a copy of the same letter dated on 8 September 1314 was also sent to the Cistercian mother houses and general chapter through Gunther de Vilestenheim, chaplain of Speyer. ${ }^{\text {xliv }}$ In all likelihood, the Italian cardinals also addressed the letter to James II, King of Aragon, who replied on 20 October 1314, offering his support for a conciliatory solution. ${ }^{\text {xlv }}$

The riots at Carpentras marked the opening of the second phase of papal vacancy, which was characterised by intense diplomatic negotiations. The Gascon cardinals had in fact gathered at Avignon, while the Italians declared that the papal election ought to take place in their presence, threatening to proceed to a papal election without the Gascons, if necessary. Indeed, according to John XXII's Vita Prima, not withstanding Ubi periculum, which decreed that papal elections should take place where the pope had died, the Italians even thought of moving the conclave back to the Roman curia. ${ }^{\text {xlvi }}$ From the very beginning of this second phase, Edward II further engaged in ongoing correspondence with his envoys, who were constantly updating him on the evolving situation 
in the South of France. One letter, addressed to the king on 31 August 1314, shows that the English Crown's envoys at the papal curia, Andrea Sapiti and Raymond Subirani, kept Edward II informed on two main issues: the agreement reached with Bertrand de Got in September 1314 on the arrears in Gascony; ${ }^{x l v i i}$ and the reluctance of the Italian cardinals to rejoin the conclave at Carpentras after the Gascon attack against it in July. ${ }^{\text {xlviii }}$ Edward II's envoy Andrea Sapiti also maintained that negotiations on the timing and location of a new conclave were taking place between one representative of the Italian cardinals, one representative of the French cardinals and Nicholas de Fréauville, cardinal of St Eusebio, emphasising the Italians' preference for Lyons or another town in the Kingdom of France as a location for the new conclave to be summoned on 1 October 1314. In the same letter the English envoy finally informed Edward II about the possible runners for papal election, hinting at Nicholas de Fréauville as the most likely candidate for election, possibly having secured the two-thirds majority, since he enjoyed the support of the French Crown, the cardinals from northern Italy (Lombardi) and Guillaume de Mandagout, cardinal-bishop of Palestrina. ${ }^{\text {xlix }}$ In a second letter addressed to Edward II only few days later, on 7 September 1314, Andrea Sapiti returned to the on-going negotiations for the summoning of the new conclave between Nicholas de Fréauville, cardinal of St Eusebio, Niccolò Albertini da Prato, cardinal-bishop of Ostia, and William Testa, cardinal of St Ciriaco in Thermis. Once more Andrea Sapiti stated the date for the conclave had been moved forward to 1 November and emphasised the Italians' preference for Lyons or another town in the Kingdom of France, while the Gascons favoured Bruges. Indeed, he informed the king that a meeting between Niccolò Albertini and Iacopo Stefaneschi had been arranged in the following weeks in order to discuss further the location of the conclave. Finally, the envoy mentioned Philip IV's pressure on the cardinals to proceed quickly to the election of Nicholas de Fréauville, asking Edward II if he wished to support openly the same candidate. ${ }^{1}$

Most interestingly, Sapiti's reference to Philip IV's appeal for a prompt papal election is further supported by a letter of the French king addressed to Bérenger Frédol and the Gascon 
Arnaud Pellegrue probably in September 1314, evidencing the good quality of the English Crown's intelligence in Avignon. ${ }^{\text {li }}$ In this letter Philip IV offered his protection to the new conclave to be summoned in the Kingdom of France as soon as possible, since the prolonged papal vacancy was affecting the Church and the organization of the crusade. The French king hence emphasised that he had engaged in correspondence with the Italian cardinals, after consultation with his legal advisers, who had sympathised with Italian concerns over joining a new conclave in Carpentras or Avignon given recent events. Equally, Lyons had emerged as the most suitable place for the new conclave, given its safety and its association with the Apostolic See, which had celebrated in the town two general councils during the thirteenth century. In Philip IV's words, Lyons was also favoured by Nicholas de Fréauville, cardinal of St Eusebio, whom the French king openly supported as a suitable candidate for the Apostolic See. Finally, Philip IV strongly reprimanded the Gascon cardinals for their open obstruction of his plans and dispatched his envoy for further negotiations. .ii $^{\text {ii }}$

Notoriously, Philip IV's pressure on the cardinals in September 1314 did not achieve any result. Indeed, while negotiations on the summoning of the new conclave came to a halt after Philip IV's death in November 1314, the Franco-Flemish war and Gascon affairs occupied the English political discourse during the first part of 1315. liii Between September 1314 and August 1315 Edward II was still very involved in the negotiations for the convocation of a new conclave, effectively managing this matter together with the business concerning the Duchy of Aquitaine. Arguably, what has so far misled the historiography, mostly unaware of Edward II's involvement in this phase of the papal vacancy, has been the current organization of the English diplomatic correspondence for these years, which was divided into different collections at the end of the nineteenth century. Indeed, as I have argued elsewhere, when the English Chancery records were moved from the Tower of London to Chancery Lane some membranes of the Roman Rolls (C 70), which contain the majority of English Crown's petitions concerning Anglo-French and Gascon affairs, were detached from the enrolments and put together with other relevant Chancery 
documentation regarding French and Gascon matters in order to create the artificial series of chancery enrolments known as Treaty Rolls (C 76). This was especially the case of membranes 7

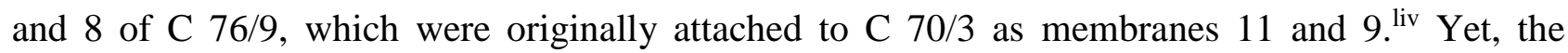
reconstruction of $\mathrm{C} 70 / 3$ as it was originally assembled in the fourteenth century allows us to shed new light on the correspondence addressed by Edward II to the cardinals in 1315, showing how Edward II tried to secure a prompt solution of the schism. On 19 November 1314 Edward II's petition addressed to the Gascon cardinals Arnaud d'Aux, Raimond Guilhem de Farges and Bernard de Garves asked for the release from the pending payment owed to the Apostolic Chamber for the visitation of Walter Reynolds, who had been translated to the archbishopric of Canterbury in 1313 and freed from any financial burden by Clement V. ${ }^{\text {lv }}$ Two weeks later, on 4 December 1314, Edward II once more wrote to the cardinals, asking for a prompt solution of the papal vacancy and announcing the dispatch of his envoys to France, Antonio Passagni and Gilberto Pecche, whose mission was also recommended to the new French king, Louis X. ${ }^{\text {lvi }}$ In the first part of 1315 Edward II was in fact involved in fresh negotiations with Louis X, who secured English support against Flanders in return for substantial concessions in Aquitaine thanks to the mission of the earl of Pembroke and the bishop of Exeter. ${ }^{\text {vii }}$ When in September 1315 his envoys Antonio Passagni and Gilberto Pecche returned from their French mission to England, Edward II newly addressed the cardinals, complaining about the long vacancy of the Apostolic See and exhorting the cardinals to unity. Indeed, the situation at the papal curia was affecting the plan for the crusade and ecclesiastical appointments in England. ${ }^{\text {lvii }}$ This was especially the case of the election to the archbishopric of York, which had been secured by William Melton on 21 January 1316. Most interestingly, faced with the prolonged papal vacancy, on 13 February 1316, Edward II urgently demanded the confirmation of William Melton's appointment, after granting him a safe-conduct to travel to the curia on 8 February. ${ }^{\text {lix }}$ On this occasion, the English chancery frustratingly had to draft a petition addressed to the "pope" without specifying a name, since the conclave had not been summoned yet. ${ }^{1 \mathrm{x}}$ 
Despite his domestic problems in 1315, Edward II therefore carried on lobbying the cardinals in order to achieve a prompt solution of the papal vacancy and along with his urgent concerns about the political affairs in Gascony. However, the historiography has traditionally argued that from early 1315 Louis X, king of France, Robert, king of Naples, and James II, king of Aragon alone took over a mediatory role in the management of the papal vacancy. ${ }^{\text {xi }}$ In particular, while France and England were occupied with the Flemish war and the Gascon affairs, the Aragonese Crown resumed its diplomatic initiative in France. On 4 January 1315 William, bishop of Gerona, was sent to Avignon and addressed to James II a dispatch concerning the rumours about the negotiations for the summoning of the new conclave, while, as a result of this diplomatic mission, the Italian cardinal Giacomo Colonna and the Gascon Arnaud Pellegrue wrote to the Aragonese king in early 1315, explaining their respective positions. ${ }^{\text {lxii }}$ In his letter to James II, dated 24 February 1315, Arnaud Pellegrue explained that the French cardinals had approached the Italian cardinals, asking them to put forward the name of a candidate for the Apostolic See and to choose a "safe" place for the conclave either in France or Provence. However, he blamed the Italians for the delay, since they had only put forward one candidate and insisted on summoning the conclave in a location under imperial control or beyond the Alps. lxiii $^{\text {. }}$

Accordingly, in December 1315 the English and Aragonese diplomatic efforts were matched by the French Crown, when Louis X dispatched Philip, count of Poitiers, on a new diplomatic mission to Avignon. ${ }^{\text {lxiv }}$ Both John of St. Victor and Bernard Gui especially praised Philip of Poitiers's embassy to Avignon in the first part of 1316, although, as Mollat's put it, they were after all the official historians of the French monarchy. ${ }^{\mathrm{lxv}}$ According to the Istore et chroniques de Flandres, during his mission Philip travelled around the residences of the cardinals in Provence in order to gather some support. ${ }^{\text {lxvi }}$ He finally met Arnaud de Pellegrue, who endorsed the French plan, and Francesco Caietani, who nevertheless opposed it. Ultimately at a meeting held at the Franciscan convent in Avignon, Philip allegedly tried to bribe some cardinals and made false accusations of 
sorcery against Francesco Caietani to discredit him. However, once more the promises made to Philip on this occasion were not followed up by any action. ${ }^{\text {lxvii }}$

Alongside James II and Louis X, in accordance with the almost contemporary accounts of Matthias von Neuenburg and Ferreto Ferreti of Vicenza, in the first part of 1316 Robert, king of Naples, took over a vital mediatory role, finally securing the summoning of the conclave at Lyons which led to the election of his candidate Jacques d'Euse. ${ }^{\text {lxviii }}$

Arguably, the Capetian and Angevin missions had the desired effects and allowed the summoning of the new conclave in Lyons in June 1316, also prompted by the sudden vacancy in the Kingdom of France, after the death of Louis X on 5 June 1316, which had left a pregnant queen and Philip of Poitiers as regent. Already in March 1316 the Aragonese ambassador at the papal curia, John Lupi de Guorga, had informed James II that the cardinals were on their way to Lyons for the conclave. ${ }^{\text {lxix }}$ On 28 June 1316 the conclave met in the Dominican convent at Lyons and began its deliberation under the armed guard of the count of Poitiers, who pressured the cardinals to reach a decision. ${ }^{\mathrm{lx}}$ In his dispatch to James II, John Lupi further remarked that, in accordance with Ubi periculum, the cardinals were not to leave the conclave until they reached a decision and that they were dubiously guarded by Philip of Poitiers along with Arnald de Comes, count of Forez, who had allowed only one chaplain and two servants to accompany each cardinal in the conclave. ${ }^{\text {xxi }}$ On 20 July 1316 another Aragonese envoy Arnald de Cumbis further described in some detail to James II the conditions of the conclave and the space used by the cardinals: they had to share connected rooms among two or three of them; they enjoined outdoor facilities during their stay, such as the convent's cloisters and gardens; and they could eat what they wished, in defiance to the papal decrees. Remarkably, the Aragonese envoy mentioned here that the count of Forez guarded its enclosure and that the conclave was only loosely run in accordance with the ruling of $U b i$ periculum, although he questioned whether the constitution applied in such case, since the place of 
Clement V's death and the audientia litterarum contradictarum were both located outside the district where the conclave had ultimately met, namely Lyons. ${ }^{\text {lxii }}$ The Aragonese envoy also explained that the King of France and the count of Poitiers had previously consulted some theologians on this point and, yet, they had decided to go ahead for the common good (propter bonum publicum) and to avoid a schism. Finally, the Aragonese envoy hinted at the count of Poitiers' plot against the election of the Gascon Arnald Novelli, cardinal of St. Prisca, who had been opposed by four cardinals acting on his behalf as well as some French cardinals, who dreaded Arnald's sympathies for James II and the king of Majorca. Indeed, the envoy concluded that the count of Poitiers preferred the election of a pope favourable to the will of the French Crown rather than the choice of a good and rightful man. In his opinion, the conclave was therefore ultimately divided into three factions: the Italians favoured the election of either Guillaume de Mandagout, cardinal-bishop of Palestrina, or Arnald Novelli; of the remaining seventeen cardinals, the French supported Bérenger Frédol, cardinal-bishop of Tusculum, and refused the election of a candidate outside the conclave, while the Gascons and the count of Poitiers preferred Arnaud Pellegrue. lxxiii Finally, the Aragonese ambassador reported on the political uncertainty in France owing to Louis X's death and the regency of the count of Poitiers, while the queen was still pregnant with the heir to the French Crown. ${ }^{\text {lxiv }}$ As the Aragonese envoy records, on 29 July 1316 this deadlock in the conclave was eventually overcome owing to a common agreement (tractatus in communi), strongly prompted by the growing pressure of Philip of Poitiers, who wished for a quick papal election, given his imminent journey to Paris and the uncertainty about the succession to the French Crown. ${ }^{1 \mathrm{xxv}}$ As the Aragonese ambassador explained in a last dispatch, dated on 7 August 1316, the choice ultimately fell on Jacques d'Euse, the elderly cardinal of Porto, because of the disagreement between the Colonna and the Caietani cardinals. ${ }^{\text {Ixxvi }}$ In a second dispatch sent on 11 August the Aragonese envoy John Lupi further explained that a difference had arisen between Napoleone Orsini and Pietro Colonna, breaking up the Italian party and eventually favouring the election of Jacques d'Euse, who was Robert of Naples' candidate supported by Arnaud Pellegrue, the Caietani 
cardinals and Napoleone Orsini. ${ }^{\text {lxxvii }}$ Equally, Giovanni Villani recounted that the Gascons supported the election either of Bérenger Frédol or Arnaud Pellegrue, while Italians, Provençals and Napoleone Orsini put forward Jacques d'Euse, who was eventually elected. ${ }^{\text {lxxviii }}$

Most interestingly, in his factious account, Villani stressed that John XXII's election was reached with the right procedure according to the decretals. ${ }^{\text {lxxix }}$ However, as Mollat put it, the sources evidently disagree on the protocol followed in the election of John XXII. While Giovanni Villani, Henry of Rebdorf, the Istore et croniques de Flandres and the Chronographia regum Francorum maintain that the election was reached per compromissum, it is likely that John XXII was in fact elected per scrutinium, as the Aragonese envoy also claims in his dispatch on 11 August 1316. ${ }^{\text {lxxx }}$ Mollat further speculated on the three members of the electoral college counting the ballots, arguing that they were Napoleone Orsini, Niccolò Albertini and Nicholas of Fréauville, while the recount was done by Bérenger Frédol, Arnaud Fournier and William Longhi. ${ }^{\text {lxxi }}$ Quoting the chronicle of Ferretto Ferretti da Vicenza, which in part agrees with John Lupi's dispatch to James II mentioned above, Mollat also maintained that the election of Jacques d'Euse was strongly promoted by Robert, king of Naples, who sent his envoy to bribe Pietro Colonna and Napoleone Orsini. lxxxii Jacques d'Euse's connections with the Angevin Crown were undeniably very strong: Jacques had been in the service of Robert's father, Charles II, as chancellor and adviser since 1298 and promoted his cause against James II, king of Aragon. Likewise, the Provençal cardinals were overall favourable to Jacques's election as he had been bishop of Avignon between 1310 and 1312..$^{1 x x x i i i}$

While no English diplomatic correspondence addressed to the cardinals during the conclave at Lyons survives, the English Crown was arguably well-disposed towards the election of Jacques d'Euse too. Jacques was in fact originally from Cahors in the region of Quercy that had been for a long time under English control. ${ }^{\text {lxxiv }}$ News of the papal election had already informally reached the king on 17 August through an agent of the Italian bankers, the Bardi. ${ }^{\text {lxxxv }}$ Between 7 August, when 
John XXII was elected, and 5 September 1316, when he was consecrated, Edward II quickly resumed his correspondence with the papal curia, addressing Arnaud Pellegrue in late August 1316 on episcopal appointments and the payment of arrears in the Duchy of Aquitaine. ${ }^{\text {lxxxvi }}$ Furthermore, on 5 September 1316 John XXII notified Edward II of his election, while on 26 September, after the consecration ceremony, Edward II again wrote to Arnaud Pellegrue, confirming that the cardinal's envoy Durand had arrived in England to inform him officially about John XXII's election. ${ }^{\text {xxxvii }}$ Finally, on 14 October 1316 Edward II's chancery drafted a first petition directly addressed to John XXII, instructing the Crown's envoys Richard Burton and John Binstead to obtain papal support against the Scots. ${ }^{1 x x x v i i i}$

As Seymour Phillips has argued, in November 1316, only few months after John XXII's election, Edward II immediately began working on the organization of a major embassy to the papal curia, led by the Aymer of Valence, earl of Pembroke, and Bartholomew of Badlesmere, which had three main concerns: the repayment of the loan of 160,000 florins made by Clement V to Edward II in 1314 in order to regain control over revenues in the Duchy of Aquitaine; the delay in the king's departure for the crusade in the Holy Land and the collection of the crusading tenths; and finally the war against the Scots. Overall, this diplomatic mission achieved satisfactory results. It in fact secured a delay of the king's crusading vow, fulfilled the Crown's requests on the collection of the crusading tenths and ensured the partial payment of the English debt at the Apostolic Chamber as well as papal support against the Scots..$^{\text {xxxix }}$

Arguably, the prompt and careful planning of the English embassy to the papal curia in late 1316 mirrors Edward II's attentive approach to Anglo-papal relations, evidenced not only in the first seven years of his reign during the pontificate of Clement $\mathrm{V}$, but also throughout the papal vacancy between 1314 and 1316. Indeed, as the English diplomatic documentation preserved at The National Archives undoubtedly shows, Edward II dispatched his envoys to Carpentras as early as 
late May 1314 and engaged in a very intense correspondence with them and the cardinals both at the time of the conclave in Carpentras and during the difficult months of negotiations for the summoning of the new conclave between the end of July 1314 and early 1315. As evidenced in the diplomatic dossier uncovered at The National Archives, during the delicate phase of negotiations that followed the attack on the Conclave at Carpentras in July 1314, Edward II regularly received information from his envoys at the papal curia, Andrea Sapiti and Raymond Subirani. In particular, Edward's envoys carefully monitored the machinations of Philip IV, who openly supported the election of Nicholas de Fréauville, cardinal of St Eusebio, and asked Edward II if he wished to support the same candidate. ${ }^{\mathrm{xc}}$ The content of such diplomatic dispatches arguably shows that Edward II was keen to be seen as an active agency in the negotiations for the election of the new pope in the second phase of the papal vacancy. This is even more remarkable given Edward II's domestic problems in the Autumn 1314, after the devastating defeat at Bannockburn, which may have prompted the king to relaunch his international profile and seek support abroad in order to face opposition at home. Furthermore, although Edward's contacts with the cardinals and the papal curia were only sporadic in the first half of 1315 and despite his domestic political and financial problems, his engagement with the papal curia in these months intersected with the difficult negotiations with the new French king Louis $\mathrm{X}$ on the Flemish war and the Gascon affairs. The election of John XXII on 7 August 1316 was undeniably achieved thanks to the diplomatic efforts of the Count of Poitiers and Robert of Naples. From August 1316 Edward II promptly resumed his contacts with the papal curia, dispatching to Avignon the Earl of Pembroke's embassy which marked a clear change in royal policy, as Phillips and Zanke have argued. ${ }^{\text {xci }}$ While Edward II and his envoys were ultimately aware of the lighter political weight that they were carrying within the international political milieu between 1314 and 1316, the English diplomatic efforts arguably ensured that the English Crown was among the political interlocutors of the cardinals during the papal vacancy and secured a place for England within the European political milieu in the second decade of the fourteenth century. 
Dr Barbara Bombi, University of Kent, Canterbury 


\section{Appendix 1}

\section{Avignon, 31 August 1314}

London, TNA, SC 1/55/47

Other editions: Langlois, Documents relatives, pp. 77-78, n. 2; Langlois, Le finds de l'Ancient, p. 450.

On the verso: "Excellentissimo ac serenissimo principi et domino domino Edwardo dei gratia regi Anglie illustri suo domino singulari”.

Letter of Andrea Sapiti, representative of Edward II at the papal curia, concerning the negotiations on the timing and location of a new conclave and names of the possible candidates for papal election.

Excellentissimo et serenissimo principi et domino domino Edwardo dei gratia regi Anglie illustri suo domino singulari suus fidelis servus Andreas Sapiti in Romana curia clericus et familiaris seipsum cum omni qua potest fidelitate ac reverentie et promptum omnibus famulatum.

Serenissime princeps et domine, scripsi vestre regie maiestati omnia que per dictum Ramundum Sobirani et me facta fuerunt cum domino marchione, quondam domini pape nepote, per plures nuncios. Et sicut dominus Ramundus et ego debebamus communiter maiestati vestre scribere et significare predicta. Et dictus dominus Ramundus, asserens mihi se magnis negociis occupatus, dicebat quod adhuc scribere non poterat nec usque nunc potuit. Et responsio marchionis, prout per alias binas litteras scripsi vestre regie maiestati, quam dominus Ramundus et ego significare debemus et mictere, fuit in effectu et est talis: quod dominus papa oneraverat eum de (volunta)te sua de quibusdam negociis faciendis et per sacramentum, et quod eum oportebat habere dictam pecuniam quam citius posset ad dicta negotia expedienda. Tamen volens placere maiestati regie vult quod sibi assignentur proventus et redditus annui costume de Marmanda et alicuius vel aliquorum locorum in ducatu, ita quod infra octo sive novem aut decem annos proxime futuros sit sibi 
satisfactum de dicto debito, facto computo diligenti [...]. Et si hoc fiat sibi alii erunt contenti et ipse cum eis de dicta assignatione et totus ducatus et proventus alii revertentur ad manus vestras et (successorum) vestrorum. Et de huiusmodi responsione sua cui effectum videre potestis dominus Ramundus et ego debemus vos certos reddere per nostras communes litteras quas mittemus maiestati vestre quando dominus Ramundus venerit ad partes istas de partibus Montipesulanis in quibus est pro negotiis domini regis Francie, ut dicit. Qui dominus Ramundus postea venit Avinionem post diem, quam assignaverat michi pro huiusmodi responsione facienda et ibidem fuit cum uno magno preceptore de ordine Hospitalorum, et cepit scribi facere litteras dirigendas vestre regie maiestati in die vigilie beati Bartholomei et illas una mecum debebat mictere mane sequenti per nostros duos communes nuncios maiestati vestre. Ipso autem mane se asserens diversis negociis occupatum, dixit quod eum oportebat ire cum quodam milite, domino Bertrando nomine, usque ad Aqua Mortuam, quem dicebat iturum pro negociis domini regis Francie ultra mare, et quod pro certo esset in Avinionem reversus die Martis proxime secutura in prandio. Nec ipsa die Martis nec Mercurii venit set die Iovis proxime misit mihi Francischinum familiarem suum, quod ipse venire non poterat Avinionem et quod micterem sibi unum nuncium, qui una cum uno de suis nuntiis maiestati vestre deferret licteras supradictas. De quo miror, quia ipse et ego illas debemus communiter mictere, et vult illas per se dirigere. Nichilominus vado ad eum ut dicta responsio non differatur ulterius et nuntium mictam cum suo, si sibi placuerit, secundum quod ipse ordinavit mecum. Nichilominus tamen effectum responsionis dicti marchionis scripsi maiestati vestre per alias licteras sicut per istas. Et cogitavi in meipso quod, si responsio marchionis vobis placeret, ad presens deberetis constituere (procuratores) vel quemdam procuratorem cum sufficienti mandato directo domino Ramundo, cuius consilio ducitur dictus marchio, quod ordinaret et notam faceret mandati ordinandi per vos in personam procuratoris vel procuratorum vestrorum quod assignarent costumam de Marmanda et aliquis alios reditus dicto marchioni, et totum alium ducatum et proventus quoslibet sine ulteriori dilatione reducerent ad manus vestre regie maiestatis. Et sic dixit se facturum. Dixit insuper dictus dominus Ramundus quod multa alia significabit maiestati vestre 
per vos utiliter in ducatu Vasconie peragenda. De quibus si significaverit, ordinabit circa illa prout ordinanda decreverit vestra regia celsitudo.

Nova et statum dominorum cardinalium et curie significavi per ordinem maiestati vestre et adhuc in eodem statu sunt. Nisi quod ipsi domini cardinales prorogaverunt primam diem Septembris qua omnes debebant recludi usque ad primam diem Octobris proxime futuri. Et dicta die prima debent recludi, et firmatum est inter eos quod eligantur duo ex ipsis cardinalibus, videlicet unus de cardinalibus Lombardis et unus de Citramontanis, qui duo sint cum domino fratre Nicolao cardinale ad providendum et firmandum de loco in quo debeant recludi, quia Carpentoratum est suspectum, et sic ab omnibus reputatur propter facinora ibidem commissa [...] recludent se in Lugduno vel in aliqua alia villa regni Francie pro certo, ita quod dictus dominus frater Nicolaus erit electus secundum preces domini regis Francie. Nam volunt omnes Lombardi eum et dominum Penestrinum et placeret multum domino regi de dicto domino Nicolao. Nam apparet quia utraque pars cardinalium elegit eum pro tertio, et sic est communis oppinio quod fiet papa. Propter quod scio et pro certo habeo, si verba promis [...] si placeret maiestati vestre regie et utile esset quod ex [...] precibus domini regis Francie, quia domini cardinales reintrabunt districtum, ita quod videretur electus ad preces vestras sicut ad preces ipsius regis Francie et ad hoc quod voluntatem dicti domini haberemus promptam pro predicationem crucis et alia opportuna contra illos Scotos [...] pessimos proditores ad destruendum eos et dampnandum ac perpetue extirpandum de hoc seculo, ita quod nullus eorum nec ipsorum iniquitas valeat perpetua esse, prout per alias litteras plene scripsi vestre regie maiestati.

Igitur celsitudinis regia michi mandare dignetur quid facere de predictis debeam cum mandatum ipsum et alia $[\ldots]$ posse $[\ldots]$ perpetue indefessus $[\ldots]$ tanquam servus fidelissimus et subiectus. Conservet altissimus vestram ${ }^{\mathrm{xcii}}$ maiestatem regiam [...] prosperitati felici per tempora prospera et longeva. 


\section{Appendix 2}

\section{Avignon, 7 September 1314}

London, TNA, SC 1/34/176; Langlois, Le finds de l'Ancient, pp. 450-451

The parchment is badly damaged on the left side. On the verso: "Excellentissimo ac serenissimo principi domino domino Edwardo dei gratia regi Anglie illustri domino suo speciali”.

Letter of Andrea Sapiti, representative of Edward II at the papal curia, concerning the on-going negotiations for the summoning of the new conclave and mentioning Philip IV's endorsement of Nicholas de Fréauville, cardinal of St Eusebio, as a candidate for the papacy.

Suo domino singulari suus fidelis servus Andreas Sapiti seipsum et promptum in omnibus famulatum.

Serenissime princeps et domine scripsi vestre regie maiestatis nova et statum curie Romane de tempore in tempus usque ad electionem factam per omnes cardinales tam Citramontanos quam Ultramontanos de tribus cardinalibus, videlicet de domino Nicolao de Francia et aliis duobus, quorum unus est dominus Ostiensis et alius dominus Guillelmus Testa, ad providendum de loco et nedum convenerunt nec ordierunt, sed in regno Francie providere intendunt, quamvis Vascones recuserit expresse Lugduni et nominant civitatem Bitrucensem prope Parisius ad XL leucas vel circa de Francia venerunt littere continentes, quod ordierunt locus et electio differatur per aliquod tempus circa festum Omnium Sanctorum. Quia unus de filiis domini regis Francie et dominus Ingerandus de Marigniaco posito negotio Flandrie in aliquo certo puncto, quod asserunt esse debere in brevi, venient ad dominos cardinales et, si differetur, venient alii probi et magni viri, ita quod sine dilatione eligatur papa et omnes Ytalici cardinales bene contentantur de fratre Nicolao et plures de aliis expresse et alii, qui nondum expresse consentiunt, videntur velle, quod rex Francie 
cognoscat plene, quod ad eius instantiam consentiant in eundem fratrem Nicolaum, in quem sine dicti domini regis precibus intimis nullatenus consentirent, ut ab eodem domino rege maiores grates reportent, ita quod dicti nuncii venturi ex parte dicti domini, ut pro certo creditur dictam electionem per preces predictas, quo ad illos, qui differunt eligere, ut rogentur, facient expediri.

Idcirco dignetur vestra regia celsitudo michi mandatum suum dirigere in eo, quod debeam de predictis facere, videlicet, si placet, quod pro dicto domino Nicolao insistam et concurram, ita quod videatur creatus in instantiam vestram, sicut domini regis Francie prefati et mandato vestro obediam nunc et semper ad posse, sicut alia scripsi de predictis vestre regie maiestati. Dominus Raymundus Sobirani scribit per suas proprias litteras responsionem, quam ipse et ego habuimus a dicto machione et ipsam mictit ista die maiestati vestre per nuntium suum, cum quo micto unum de meis, ita quod directe ducat dictum nuncium domini Raymundi ad pedes vestre regie maiestatis. Dominus Hostiensis prefatus rogavit consotios suos cardinales, quod placeret eis de seipsis ad eligendum de loco alium nominare, ita quod ipse vel dominus Jacobus Gaytanus mictetur ad predicta loco sui et convenient de septimana futura, ubi tamen nescitur adhuc, sed creditur, quod in Montiliis ad Mare aut in Sancto Spiritu vel in civitate Vivariensi.

Conservet altissimus vestram maiestatem regiam ipsamque augeat in honore et prospiritate felici.

Datum Avinionis, die Sabbati in Vigilia beate Marie Virginis Gloriose. 


\section{Appendix 3}

\section{Lancaster, 13 Feburary 1316}

London, TNA, C 70/ m. 8.

Petition of Edward II to the "pope”, urgently demanding the confirmation of William Melton's appointment as archbishop of York.

Pape rex devota pedum oscula beatorum.

Sacrosancte Romane ecclesie, que disponente Domino omnium ecclesiarum optinet principatum, decet regimini perfidentem ad ecclesias pastoribus viduatas et que precipue immediate eidem Romane ecclesie sint subiecte, eo solercius oculos paternales, quo sit pastoris solacio destitute, calamitatibus et angustiis noscuntur periculosis subiacere vacante siquidem nuper Eboracensi ecclesia per mortem bone memorie Willelmi nuper archiepiscopi loci illius petitaque a nobis, ut est moris, eligendi licencia et optenta, decanus et capitulum eiusdem ecclesie ad electionem de summo pontifice procedentes ac ad personam predicti et familiaris clerici nostri magistri Willelmi de Melton, canonici eiusdem ecclesie, cuius vite a conversacionis mundiciam ac fidelitatem probitatem per ea que tam clare memorie .. genitoris nostri quam nostro lateribus assistente fideliter et utiliter gessit officia liquido cognoverunt ac vix subiecti nobis pepuli concordi preconio approbat et divulgat sue consideracionis intuitum dirigentes ipsum in suum archiepiscopum, concorditer elegerunt et nobis per suas patentes litteras presentarunt pro assensu nostro regio optinendo.

Nosque licet eiusdem electi presenciam propter ipsius circumspectionis et industrie probitatem in nostris dirigendis negociis perutilem videremus, sperantes tamen ex perfectione eiusdem in ecclesia supradicta non solum ipsi ecclesie set nobis et toti regno nostro uberiora commoda divina sibi suffragante clemencia affutura electioni huiusmodi nostrum assensum regium 
duximus adhibendum. Quamobrem, sanctitati vestre, votivis affectibus supplicamus, quatenus eiusdem electum virum utibus moribus pudicum, devocione conspicuum litterarum sciencia predictum in gubernacione spiritualium et temporalium industrium et probacionem et universa morum honestate preclarum, qui ad pedes vestre beatitudinis pro confirmacione electionis predicte ac consecrationis munere optinendum se divertit, habentes, si placet, nostri consideracione propensius commendatum ac ad ${ }^{\mathrm{xciii}}$ periculosa dispendia, quibus eiusdem ecclesia multipliciter exponitur hiis diebus dampna, etiam que ex subiectione circumspectionis et consilii dicti electi, in quo in nostris et dicti regni negociis dirigendum, nostra fiducia precipue requiescit paterne consideracionis intuitum, dirigentes eiusdem electum eo graciosius et celerius iubere dignemini expediri, quo nostris affectibus intimius coniungitur et ex eius promocione tranquillitati et quieti regni nostri specialiter uberius consulendum et ut nos affectionis magnitudinem, quam ad nos et idem regnum nostrum innatam vestram clemenciam habere confidemus, ex ipsius expedicione celeri et votiva sentire operis efficacia valeamus, vestris exinde beneplacitis forcius perpetuo obligati ad exaltacionem et cetera.

Datum Lancastrie, xiii die Februarii. 
* I am most grateful to Dr Patrick Zutshi for his very helpful comments on this article and to Dr Armand Jamme for sharing with me his forthcoming work on this topic.

' Guillaume Mollat, Les papes d'Avignon, 1305-1378, Paris 1949, 30-32; Yves Renouard, La papauté à Avignon, Paris 1954; English translation The Avignon papacy, London 1970), 20-21; Bernard Guillemain, La cour pontificale d'Avignon, 1309-1376. Étude d'une société, Paris 1966, 129-130; Jeffrey Denton, 'Pope Clement V's early career as a royal clerk', English Historical Review lxxxiii (1968), 303-314; Jean-Paul Trabut-Cussac, L'administration anglaise en Gascogne sous Henry III et Edouard I de 1254 a 1307, Genève 1972, 131; Jeffrey Denton, Robert Winchelsey and the crown, 1294-1313. A study in the defence of ecclesiastical liberty, Cambridge 1980, 219-220; Robert Wright, The Church and the English Crown, 1305-1334, Toronto 1980, 168; Patrick N.R. Zutshi, 'Some early letters of Pope Clement V (1305-14) in the Public Record Office', Archiv für Diplomatik xxxiii (1987), 323-335; Patrick N.R. Zutshi, 'The letters of the Avignon Popes (1305-1378): a Source for the Study of Anglo-Papal Relations and of English Ecclesiastical History', in Michael Jones and Malcolm Vale (eds), England and her neighbours, 1066-1453. Essays in 
honour of Pierre Chaplais, London - Ronceverte 1989), 259-275. M. Prestwich, Edward I (London, 1988), 532-533. Sophia Menache, Clement V, Cambridge 1998, 9-30; Jean Favier, Les papes d'Avignon, Poitiers 2006, 50-51;

ii Wright, The Church, 169.

iii Wright, The Church, 169-171. See Frederick-Thomas Tout and Hilda Johnstone, The Place of the Reign of Edward II in English History, Manchester 1936, 230-233; William A. Pantin, The English Church in the Fourteenth Century, Cambridge 1955, 77; Mary McKisack, The Fourteenth Century, 1307-1399, Oxford 1959, 283-285.

iv Zutshi, 'The letters of the Avignon Popes', 263-265; Peter Heath, Church and Realm: 1272-1461: conflict and collaboration in an age of crises, London 1988, 65; 91-92. Similarly, Seymour Phillips, Edward II, New Haven London 2010, 448-451, recently argued that 'for most his reign Edward II had been on good terms with both the English Church and the papacy'.

${ }^{\mathrm{v}}$ Phillips, Edward II, 238-279.

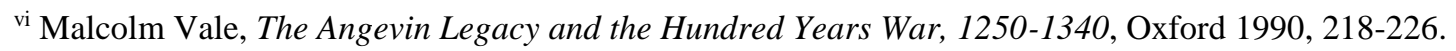

vii Vale, The Angevin Legacy, 228.

viii Vale, The Angevin Legacy, 228; Phillips, Edward II, 247. See also George P. Cuttino, English Diplomatic Administration, 1259-1339, Oxford 1940, 12-15; Elizabeth A.R. Brown, 'Gascon subsidies and the finances of the English dominions, 1315-1324, Studies in Medieval and Renaissance History viii (1971), 34-153; Elizabeth A.R. Brown, 'Diplomacy, Adultery, and Domestic Politics at the Court of Philip the Fair: Queen Isabelle's Mission to France', in Jeffrey Hamilton (ed), Documenting the past. Essays in Medieval History presented to G.P. Cuttino, Woodbridge 1989, 53-83.

ix Wright, The Church, 101-102; 125-128. Guillemain, La cour pontificale, 451-479, also emphasised that very few English curialists were appointed and present at Avignon in the early fourteenth century - Clement V in fact only appointed one English auditor of causes, while the largest number of English curialists was appointed during the pontificate of John XXII.

${ }^{\mathrm{x}}$ Brief mentions of the letters sent from France to Edward II by his representatives are made in Charles V. Langlois, 'Le fonds de l'Ancient Correspondence au Public Record Office de Londres', Journal des Savants ii (1904), 446-453; Charles V. Langlois, 'Notices et documents relatifs a l'histoire du XIII et du XIV siècle', Revue historique lxxxvii (1905), 76-79.

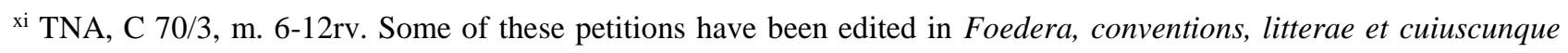
generis acta publica inter reges Anglie et alios quosvis, ed. T. Rymer - R. Sanderson, II/1, London 1816-1830.

xii TNA, SC7/56/3; Foedera, II/1, 254. 
xiii TNA, SC1/55/47; Appendix 1 and TNA, SC1/34/176; Appendix 2. These two documents had briefly been mentioned in Langlois, 'Le fonds de l'Ancient', 446-453; Langlois, 'Notices et documents', 76-79.

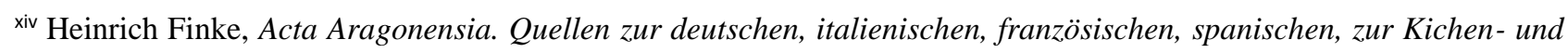
Kulturgeschichte aus der diplomatischen Korrespondenz Jaymes II. (1291-1327), Berlin-Leipzig 1908, I, nos 131-149, 200-231. See also Guillaume Mollat, 'L'élection du pape Jean XXII', Revue d'histoire de l'Église de France (1910), reprinted in i (1967), 147-166.

${ }^{\mathrm{xv}}$ Gratian, Decretum, D. 23 c. 1.

${ }^{x v i}$ X 1.6.6. Agostino Paravicini Bagliani, Il Trono di Pietro. L'universalità de papato da Alessandro III a Bonifacio VIII, Roma 1996, 13-18; Alberto Melloni, Il conclave. Storia dell'elezione del Papa, Bologna 2001, 19-43.

${ }^{\text {xvii }} X$ 1.6.42. Ultimately, in 1234 both Licet de vitanda and Quia propter were received into the Liber Extra, the collection of decretals commissioned by Gregory IX. The three kinds of voting are clarified in Bernard of Parma's Glossa Ordinaria on Licet de vitanda, printed with the Liber Extra, Paris 1529, fo. 37, as well as in Goffredus de Trano, Summa in titulis decretalium, Venice 1564, fo. 5rab. See also Peter Herde, 'Election and abdication of the pope: Practice and doctrine in the thirteenth century', in Stephan Kuttner and Kenneth Pennington (eds), Proceedings of the Sixth International Congress of Medieval Canon Law (Berkeley, 28 July-2 August 1980), Città del Vaticano 1985, 411436.

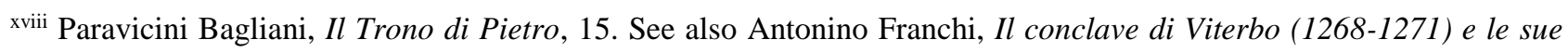
origini Ascoli Piceno 1993, 23-24.

${ }^{x i x}$ This was the case of the election of Innocent IV after Celestine IV's death (10 November 1241-25 June 1243); the election of Clement IV after Urban IV's death (1264-1265, four months); and the election of Gregory X after Clement IV's death, which took thirty-three months (1268-1271). Jean Porcher, 'Lettres émanant de la cour pontificale à l'époque du conclave de Viterbe (1270-1272)', Melanges d'Archéologie et d'Histoire de l'Ecole Française de Rome lx (1923), 123-134; Franchi, Il conclave di Viterbo; Luigi Gatto, 'Il conclave di Viterbo nella storia della elezioni pontificie del '200', in Atti del convegno di studio. VII centenario del I conclave (1268-1271), Viterbo 1975, 37-62; Agostino Paravicini Bagliani, 'Versi duecenteschi su un conclave del secolo XIII', in Miscellanea G.G. Meersseman, Padova 1970, I, 151-169.

${ }^{\mathrm{xx}}$ These were: in 1281 (Martin IV's election); in 1288 (Nicholas IV's election); and in 1294 (Celestine V's election).

${ }^{x x i}$ VI 1.6.3. See also Paravicini Bagliani, Il Trono, 16-18; Agostino Paravicini Bagliani, Il corpo del Papa, Torino 1994, 218-220; Melloni, Il conclave, 45-47. 
xxii Giovanni Fornaseri, 'Il conclave Perugino del 1304-1305', Rivista di storia della Chiesa in Italia x (1956), 321-344; Silvestro Nessi, Il conclave di Perugia (1304-1305), Perugia 2010.

xxiii Clem. 1.3.2. See also Paravicini Bagliani, Il corpo del Papa, 220-223.

${ }_{\text {xxiv }}$ Mollat, Les papes, 38; Mollat, 'L'élection', 151.

${ }^{x x v}$ Guillaume Mollat, Étude critique sur les Vitae paparum Avenionensium d'É. Baluze, Paris 1917, 86-101.

xxvi Vitae paparum Avenionensium, ed. É. Baluze, nouvelle édition par G. Mollat, Paris 1914-1917, I, 107: 'Fuerunt ergo diu in tali discordia, licet inclusi multa incommoda sustinerent, quia cibaria eorum subtrahebantur et domus eorum desuper dissipate'.

xxvii Mollat, Les papes d'Avignon, 37-40.

xxviii Vitae paparum Avenionensium, II, no xliii, 238: 'Nam nunc volens Ecclesiam reducere ad angulum Vasconie, talia que scimus pro certo conceperat et iam ordinaverat quod vere se ipsum, si complesset, et ecclesiam destruxisset'. On Napoleone Orsini see Giulia Barone, 'Orsini, Napoleone', in Dizionario Biografico degli Italiani lxxix, Roma 2013, 677-681.

${ }^{x x i x}$ Fornaseri, 'Il conclave Perugino', 328; 343; Nessi, Il conclave di Perugia, 45-57.

${ }^{x x x}$ Dante Alighieri, 'Epistola VIII', in Dantis Alagherii Epistolae, ed. P. Toynbee, Oxford 1966, § 10, 139-141: ‘Tu prae omnibus, Urse, ne degradati collegae, perpetuo remanerent inglorii; et illi, ut militantis Ecclesiae veneranda insigna, quae forsan non emeriti sed immeriti coacti posuerant, Apostolici Culminis auctoritate resumerent. Tu quoque, Transtiberinae spectator factionis alterius, ut ira defuncti Antistitis in te velut ramus insitionis in trunco non suo frondesceret, quasi triumphatam Carthaginem nondum exueras, illustrium Scipionum patriae potuisti hunc animum sine ulla tui iudicii contractio praeferre?'. See also Cronica di Giovanni Villani, ed. G.F. Dragomanni, II, Firenze 1845, lib. IX, ch. cxxxvi, 234.

xxxi Vitae paparum Avenionensium, II, no xliii, 239.

xxxii Vitae paparum Avenionensium, II, no xliii, 239-240: 'Hic dominus Guillermus, Dei gratia episcopus Penestrinus, de quo nos populus et clerus credidimus quod statim Vascones acceptarent sine aliqua questione. Propter quod tantam resistentiam reperientes stupuimus, nec apud nos huiusmodi resistentie reperire possumus causam, nisi forte, quod absit, crediderint aliqui premissos defuncti continuare defectus.'

xxxiii Vitae paparum Avenionensium, II, no xliii, 240: 'Ne credo nunc sapientiam regiam fore nocivam'. See also Fornaseri, 'Il conclave Perugino', 328; 343. Dante Alighieri, 'Epistola VIII', § 11, 142, also balmes the Gascons for the delayed papal election in 1314: 'et ut Vasconum Latinorum gloriam sibi usurpare contendunt, per saecula cuncta future sit posteris in exemplum'. 
xxxiv TNA, C 70 / 3, m. 12v; Foedera, II/1, 247-248. See also Vale, The Angevin Legacy, 170.

xxxv TNA C 70/3, m. 12v; Foedera, II/1, 249: 'ad provisionem canonicam, per consensum unanimem, et electionem concordem, sine more dispendio procedatis'. See also Norman Housley, The Avignon Papacy and the crusades, 1305 1378, Oxford 1986, 14-15.

xxxvi TNA C 70/3, m. 12v; Foedera, II/1, 249-250: 'Totis conatibus laboretis, et dictos confratres vestros, quantum ad vos pertinent, modis et viis licitis inducatis, ut, per electionem canonicam, provideatur celeriter de pastore'.

xxxvii TNA, C 70/3, m. 11v; Foedera, II/1, 251. On this matter see also Gascon Rolls preserved in the Public Record Office, 1307-1317, ed. Y. Renouard, London 1962, no 688, 193; no 877, 241.

xxxviii Parravicini Bagliani, Il corpo del papa, 221-223, has pointed out that from the fourteenth century during papal vacancies papal powers were passed on to the cardinals and especially to the camerarius, who was not normally a cardinal, and major penitentiary.

xxix TNA, SC 7/56/3; Foedera, II/1, 254. On the verso of the letter is still possible to see traces of five mandola red wax seals, namely the seals of the five cardinals that issued the letter. The only Italian cardinal who is not mentioned among the senders of the letter is Iacopo Stefaneschi. The copy preserved at TNA is the only surviving original of the cardinals' letter.

xl Fornaseri, 'Il conclave Perugino', 330-331, emphasised the hostility between Napoleone Orsini and Iacopo Stefaneschi, a former supporter of Pope Boniface VIII, during the conclave in Perugia in 1304-1305. See also Barone, 'Orsini, Napoleone', 679.

xli TNA, SC 7/56/3; Foedera, II/1, 254: 'et nos cardinales Italici non querentes quae nostra sunt, sed quae Dei, neglectis singularibus affectionibus reciprocis in nosipsos, peteremus hominem ad sustentandas columpnas ecclesie, qui dictam ecclesiam reformando diligeret, essetque in hoc tantum omnis nostra cura, omnis intentio, hic affectus'.

xlii TNA, SC 7/56/3; Foedera, II/1, 254: 'Vascones, seu quod libram examines sub futuro pontifice, teste conscientia, formidant, seu quod armorum violentia crederent, hereditario iure, Dei sanctuarium possidere'.

xliii TNA, SC 7/56/3; Foedera, II/1, 254: 'multitude Vasconum armatorum, hostium conclavis obsedit, acclamando 'Moriantur cardinals Italici, moriantur, volumus Papam, volumus Papam'.

xliv Vitae paparum Avenionensium, II, no xlii, 234-237.

${ }^{x l v}$ Finke, Acta Aragonensia, I, no 131, 200-202.

${ }^{\text {xlvi } V i t a e ~ p a p a r u m ~ A v e n i o n e n s i u m, ~ I, ~ 107: ~ ' E t ~ l i c e t ~ s e c u n d u m ~ s t a t u t u m ~ i n ~ u r b e ~ q u o ~ m o r i t u r ~ p a p a ~ d e b e a t ~ e l e c t i o n e m ~}$ celebrari; tamen Italici omnino discordabant, volentes quod electionem ad curiam Romanam transferretur et alii alibi. Ideo sunt dispersi'. 
xlvii Brown, 'Gascon subsidies', 72-73.

xlviii TNA, SC 1/55/47; Langlois, Documents relatives, 77-78, 2n.. The second part of this document is confusingly published in Langlois, Le finds de l'Ancient, 450, as a separate document. See Appendix 1.

xlix Appendix 1.

${ }^{1}$ TNA, SC 1/34/176; Langlois, Le finds de l'Ancient, 450-451. See below Appendix 2.

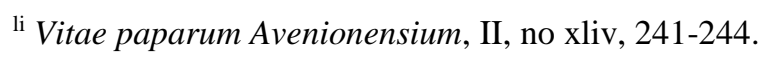

lii Vitae paparum Avenionensium, II, no xliv, 242. Most interestingly Philip IV maintained that his advisers were learned in both laws (in utroque iure periti), clearly implying that moving the conclave to another place in France would have meant to overrule the canonical constitutions on papal elections, Ubi periculum and Ne Romani, where it was stated that the conclave had to meet in the papal palace, or in another residence, if the pope had died in another location, or ultimately in the place where the audientia litterarum contradictarum was located at the time of the pope's death. Equally, these canonistic rules would have also excluded holding conclave at Lyons.

liii Treaty Rolls preserved in the Public Recod Office, I, ed. P. Chaplais, London 1955, 214-222 (esp. nos 539-549, 214217), formerly part of C 70/3.

liv Barbara Bombi, 'The Roman rolls of Edward II as a source of administrative and diplomatic practice in the early fourteenth century', Historical Research 1xxxv (2012), 607-608. See also Chaplais, Treaty Rolls, 211-217.

${ }^{\text {lv }}$ C 70/3, m. 11v; Foedera, II/1, 257-258.

Ivi C 70/3, m. 10; Foedera, II/1, 258, and Treaty Rolls, no 536, 210; Foedera, II/1, 259.

lvii Brown, 'Gascon subsidies', 73-102; Phillips, Edward II, 247-248. See also Treaty Rolls, nos 539-546, 214-216.

lviii C 70/3, m. 8; Foedera, II/1, 277; C 70/3, m. 10; Foedera, II/1, 278-279.

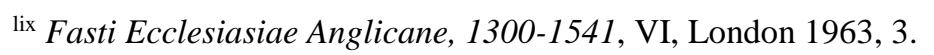

${ }^{\mathrm{lx}} \mathrm{C} 70 / 3$, m. 8. A second petition on the same matter was addressed to Bérenger Frédol, papal penitentiary and regent during the papal vacancy. See below Appendix 3.

lxi See Mollat, 'L’élection', 147-166.

Ixii Finke, Acta Aragonensia, I, nos 132-134, 202-206.

Ixiii Finke, Acta Aragonensia, I, no 134, 204-206.

Ixiv Joseph Lehugeur, Histoire de Philippe le Long, roi de France (1316-1322), Paris 1897, 24-26. See also Henricus Rebdorfensis, Annales imperatorum et paparum, 1294-1362, in Heinricus de Diessenhofen und andere Geschichtsquellen Deutschlands in späteren Mittelalter, ed. J.F. Bohmer, (Fontes rerum Germanicarum IV, 1868 ), 553. 
${ }^{\mathrm{lxv}}$ Vitae paparum Avenionensium, I, 114; 115;Vitae paparum Avenionensium, I, 152-153. Bernard Gui’s Vita Tertia is included in the Flores chronicorum and was written in seven recensions between 1305 and 1328. See also Mollat, Étude critique, 22-30; Mollat, 'L'élection', 148-149. On Philip of Poitier's mission to Avignon see also Les Grandes Chroniques de France, ed. J. Viard, VIII, Paris 1934, ch. vi, 327; Heinricus de Diessenhofen und andere Geschichtsquellen Deutschlands in späteren Mittelalter, ed. J.F. Bohmer (Fontes rerum Germanicarum IV, 1868), ch.1, 16; Thomas de Burton, Chronica monasterii de Melsa, ed. A. Bond (Rolls Series 43/2, 1867), 318.

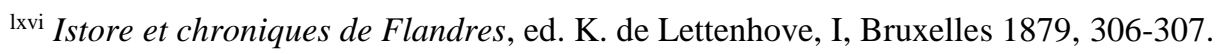

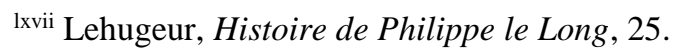

Ixviii Matthiae Nuewenburgensis, Cronica, 1273-1350, in Heinricus de Diessenhofen und andere Geschichtsquellen Deutschlands in späteren Mittelalter, ed. J.F. Bohmer (Fontes rerum Germanicarum IV, 1868), 190; Ferreti Vicentini, Historia, in Rerum Italicarum Scriptores, ed. L.A. Muratori, IX, Mediolani 1726, col. 1166-1169. On Jacques d'Euse see Mollat, 'L’élection’, 63. See also John E. Weakland, 'John XXII before his pontificate, 1244-1316: Jacques Duèse and his family', Archivum Historiae Pontificiae x (1972), 164-168.

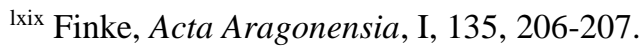

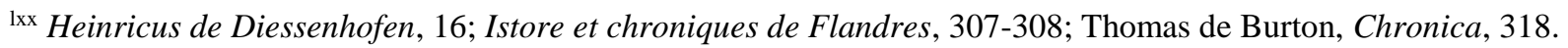

lxxi Finke, Acta Aragonensia, I, no 136, 207-208. See also Mollat, 'Lélection', 150-151.

lxxii On the constitutions see above n. xxi-xxiii. See also Mollat, 'Lélection', 151-152.

lxxiii Finke, Acta Aragonensia, I, no 137, 208-210. See also Mollat, 'L’élection', 152-153.

${ }^{\text {lxxiv }}$ Finke, Acta Aragonensia, I, no 137, 210-211.

${ }^{\operatorname{lxxv}}$ Finke, Acta Aragonensia, I, no 138, 211-212. Mollat, Vita Tertia, 153: 'tandem tractatu perhabito ... omnes partes consensierunt' (this source also tells us that the cardinals present at the election were 23). The same wording in Mollat, Vita Quarta, 169; very similar, although shorter account, in Mollat, Vita Quinta, 172; Mollat, Vita Sexta, 178. There is no mention of the divisions in the conclave in Mollat, Vita Secunda, and Vita Septima. See also Mollat, 'L'élection', 147-159. See also Renouard, The Avignon papacy, 25 ; Favier, Les papes d'Avignon, 121-126.

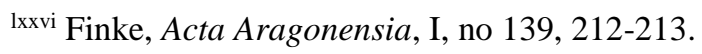

lxxvii Finke, Acta Aragonensia, I, no 141, 215-216.

lxxviii Cronica di Giovanni Villani, II, lib. IX, ch. 1xxxi, 198-199. Equally, the Annales Florentini, 1288-1431, in Heinricus de Diessenhofen und andere Geschichtsquellen Deutschlands in späteren Mittelalter, ed. J.F. Bohmer, (Fontes rerum Germanicarum IV, 1868), 676, argue that Jacques d'Euse voted for himself. 


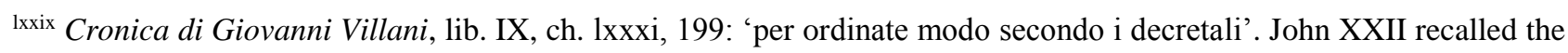
nature of his election in a letter addressed to the archbishop of Reims on 5 September 1316: Lettres secrètes et curiales du pape Jean XXII, ed. A. Coulon, Paris 1943, I, no 2, col. 5-6.

${ }^{\text {Ixxx }}$ Finke, Acta Aragonensia, I, no 141, 215.

lxxxi Mollat, 'L’élection', 154-158.

Ixxxii Ferreti Vicentini, Historia, col. 1166-1167; Mollat, 'L’élection', 159. See above n. 1xxx.

lxxxiii Mollat, 'L'élection', 163. See also Weakland, 'John XXII', 164-168; Thierry Pécout, 'Jacques Duèze, éveque de Fréjus (1300-1310)', in Julien Théry (ed), Jean XXII et le Midi, Toulouse 2012, 53-82; Thierry Pécout, 'Fréjus, ses èveques et les comtes angevins autour de 1300: 1'éepiscopat de Jacques Duèze', in Jean-Paul Boyer and T. Pécout, $L a$ Provence et Fréjus sous la première maison d'Anjou 1246-1382, Aix-en-Provence 2010, 93-120.

lxxxiv Mollat, 'L'élection', 161; 168. See also Armand Jamme, 'Les couronnements lyonnais de Clément V et de Jean XXII. Imperium pontifical et monarchie française', in Lyon, de l'empire au royaume, Colloque international organisé par le Ciham et le GDR Capétiens Autour du rattachement de la ville de Lyon à la France 7e Centenaire du Traité de Vienne (27-29 September 2012), forthcoming.

${ }^{\text {Ixxxv }}$ On the dispatch of the news concerning John XXII's election through the Bardi see Wardrobe Book 10 Edward II (1316-1317): London, Society of Antiquaries London, ms. 120, fol. 48; John Gage, 'A brief summary of the Wardrobe accounts of the tenth, eleventh and fourteenth years of King Eduard the Second, contained in the letter addresses by Thomas Stapleton', Archaelogia xlviii (1885), 281-284; Catalogue of Manuscripts in the Society of Antiquaries of London, ed. P.J. Willetts, London 2000, 56. See also Phillips, Edward II, 284, 22n.

Ixxxvi TNA, C 70/3, m. 6-7 and Foedera, II/1, 294-295. In one of this petitions dated 20 August 1316 Edward II recommended the promotion of Geffrey of Aylesham to the archbishopric of Cashel before his proctor at the papal curia, Andrea Sapiti, asking him to represent his candidate before the pope. The Aragonese Crown also resumed petitioning the curia soon after John XXII's election: Finke, Acta Aragonensia, I, no 140, 21-214; 142-144, 217-222. Ixxxvii Jean XXII (1316-1334). Lettres communes, ed. G. Mollat, Paris 1904, no 4891; TNA, C 70/3, m. 10v; Foedera, II/1, 297. According to Wright, The Church, 310, Arnaud Pellegrue was one of the closest cardinals to English Crown during Edward II's reign.

Ixxxviii TNA, C 70/3, m. 5; Phillips, Edward II, 284-286.

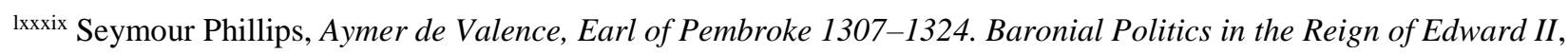
Oxford 1972, 107-11; Phillips, Edward II, 284-287; Sebastian Zanke, Johannes XXII., Avignon und Europa. Das politische Papsttum im Spiegel der kurialen Register (1316-1334), Leiden - Boston 2013), 214-222. See also Barbara Bombi, 'Andrea Sapiti: His Origins, and His Register as a Curial Proctor', English Historical Review, cd (2008), 134. 
${ }^{x c}$ See above, n. 1; below, Appendix 2.

xci Phillips, Aymer de Valence, 107; Zanke (Johannes XXII., 222) agrees with Philips on the changing nature of the Earl of Pembroke's mission to Avignon, which aimed at enlisting papal aid against the Scots and other urging domestic problems. However, he disagrees on the lasting legacy of this mission, which has been discounted by Phillips as having 'little permanent value'.

xcii Superscript.

xciii Superscript. 